Connecticut College

Digital Commons @ Connecticut College

2020

Resistance and resilience of Virgin Islands bird populations

following severe hurricanes

Robert A. Askins

David N. Ewert

Follow this and additional works at: https://digitalcommons.conncoll.edu/biofacpub

Part of the Ornithology Commons

This Article is brought to you for free and open access by the Biology Department at Digital Commons @ Connecticut College. It has been accepted for inclusion in Biology Faculty Publications by an authorized administrator of Digital Commons @ Connecticut College. For more information, please contact bpancier@conncoll.edu.

The views expressed in this paper are solely those of the author. 


\title{
Resistance and resilience of Virgin Islands bird populations following severe hurricanes
}

\author{
Robert A. Askins ${ }^{1 *}$ and David N. Ewert ${ }^{2}$
}

\begin{abstract}
We analyzed changes in abundance of terrestrial birds on St. John, U.S. Virgin Islands, for a 32 year period during which 3 major hurricanes occurred. Using 1987 as a baseline year, because it followed a 27 year hiatus when no major hurricanes hit the island, we assessed the impact of hurricanes on vegetation structure and bird populations. Bird abundance was determined for $25 \mathrm{~m}$ radius circular plots that were surveyed each year of the study along the same transects. Percent cover of trees, shrubs, and herbs was measured in each plot in 1987, 1990, and 2019. All of the survey plots were in moist forest or dry woodland in Virgin Islands National Park. Of 13 common birds, 5 did not show marked and consistent declines in abundance following hurricanes even though the structure of vegetation on the island was heavily modified by storms. Three of these species are insectivores. Seven species declined or showed habitat shifts following Hurricane Hugo in 1989, but 5 of these populations subsequently increased and most recovered to close to their 1987 abundance during the 1990s. Six of these 7 species also declined or showed habitat shifts following Hurricanes Irma and Maria in 2017. The most marked declines in the aftermath of hurricanes in both 1989 and 2017 were for frugivores and nectarivores, especially hummingbirds. Most common bird species in Virgin Islands National Park were either resistant to the effects of severe hurricanes or resilient in the decade following a hurricane. However, more research is needed to assess the status of vulnerable species such as hummingbirds and rare resident species (Bridled Quail-Dove [Geotrygon mystacea] and Puerto Rican Flycatcher [Myiarchus antillarum]). Received 9 April 2020. Accepted 22 February 2021.
\end{abstract}

Key words: Caribbean, cyclonic storms, habitat disturbance, island birds, island populations, migratory birds, population trends.

Resistencia y resiliencia de las poblaciones de aves de las Islas Vírgenes después de huracanes severos

RESUMEN (Spanish) - Analizamos los cambios en la abundancia de aves terrestres en St. John, en las Islas Vírgenes de los Estados Unidos, por un periodo de 32 años durante los cuales ocurrieron 3 grandes huracanes. Usando 1987 como el año base, porque éste siguió a una pausa de 27 años durante los cuales ningún gran huracán golpeó la isla, determinamos el impacto de huracanes en la estructura de la vegetación y las poblaciones de aves. La abundancia de aves fue determinada en parcelas circulares de $25 \mathrm{~m}$ de radio que fueron muestreadas cada año a lo largo de los mismos transectos. El porcentaje de cobertura de árboles, arbustos y hierbas fue medido en cada parcela en 1987, 1990 y 2019. Todas las parcelas de muestreo fueron hechos en bosques húmedos o arbolados secos del Virgin Islands National Park. De 13 aves comunes, 5 no mostraron declines marcados y consistentes en abundancia después del paso de huracanes si bien la estructura de la vegetación en la isla fue fuertemente modificada por estas tormentas. Tres de estas especies fueron insectívoros. Siete especies declinaron o mostraron cambios de hábitat después del huracán Hugo en 1989, aunque 5 de estas poblaciones subsecuentemente se incrementaron y la mayoría se recuperaron cercanamente a sus abundancias de 1987 durante la década de 1990. Seis de estas 7 especies también declinaron o mostraron cambios de hábitat después de los huracanes Irma y María en 2017. Los declines más marcados como secuela de huracanes en 1989 y 2017 fueron para frugívoros y nectarívoros, especialmente colibríes. Las especies más comunes en el Virgin Islands National Park fueron resistentes a los efectos de huracanes severos o resilientes en la década posterior a un huracán. Sin embargo, necesitamos más investigación para determinar el estatus de especies vulnerables como colibríes y especies residentes raras (la paloma Geotrygon mystacea y el mosquero Myiarchus antillarum).

Palabras clave: aves insulares, aves migratorias, Caribe, perturbación de hábitat, poblaciones insulares, tendencias poblacionales, tormenta ciclónica.

Bird species that are restricted to islands are particularly vulnerable to extinction. Although islands only make up 5\% of the land area on Earth, $95 \%$ of extinct species and $59 \%$ of species listed as critically endangered by the IUCN are endemic to islands (Tershy et al. 2015, Spatz et al. 2017). Island endemics are more prone to extinction than most continental species because they have smaller populations and more restricted

\footnotetext{
${ }^{1}$ Department of Biology, Connecticut College, New London, CT, USA

${ }^{2}$ American Bird Conservancy, The Plains, VA, USA

* Corresponding author: raask@conncoll.edu
}

distributions, making them especially vulnerable to habitat destruction and the negative effects of introduced predators, pathogens, and competitors (Johnson and Stattersfield 1990, Tershy et al. 2015). The restricted distribution and small population sizes of island bird species also make them vulnerable to the effects of natural disturbances such as hurricanes (Simberloff 2000, Moreno et al. 2018), a factor that may become increasingly important as hurricanes intensify with climate change (Bhatia et al. 2019).

Hurricanes can cause major population declines in some species of terrestrial landbirds (Wiley and Wunderle 1993, Johnson and Winker 2010). The 
main cause of these declines appears to be severe reduction in food availability in the months following a major storm. When wind speeds exceed $130 \mathrm{~km} / \mathrm{h}$ most trees lose their leaves, which may prevent the loss of major branches or the toppling of the entire tree (Francis and Gillespie 1993). Flowers and fruit are also stripped off of trees and shrubs, and these resources remain scarce while plants are growing new leaves (Wunderle 1999). As a result, bird species that specialize on nectar or fruit often show severe population declines in the months following a major storm (Askins and Ewert 1991, Wauer and Wunderle 1992, Wunderle et al. 1992, Foster et al. 2004, Lloyd et al. 2019). In contrast, insectivores typically show little or no change in abundance (Askins and Ewert 1991, Waide 1991a, Wauer and Wunderle 1992) because insects are common in the flush of new plant growth that quickly follows a storm (Torres 1992, Schowalter et al. 2017).

Even though some Caribbean island populations decline following hurricanes, hurricanes are frequent enough that they constitute a natural disturbance regime to which resident species may be well-adapted (Varty 1991, Walker et al. 1991, Akresh et al. 2021). Many bird species adjust quickly to changes in vegetation structure and availability of different types of food following these storms (Waide 1991a). However, extensive anthropogenic habitat destruction may result in even more restricted geographical ranges and smaller populations for island species, making their populations increasingly susceptible to population declines or extinction following natural disturbances (Haney et al. 1991, Simberloff 2000). Furthermore, climate models predict that global warming will lead to more intense hurricanes in the future (Ercolani et al. 2015, Bhatia et al. 2019), which could lead to even more severe vulnerability of island bird populations (Field et al. 2019). Although it is difficult to confirm long-term trends because of historical variation in hurricane intensity and the lack of accurate data from the period before weather satellites, recent analyses indicate that the number of extremely intense hurricanes is increasing (Bhatia et al. 2019, Knutson et al. 2019). In 2017 the U.S. Virgin Islands were hit by 2 Category 5 hurricanes that were the most powerful storms ever recorded in this island group (HurricaneCity 2020a, 2020b for Hurricanes Irma and Maria, respectively), which is consistent with the projected increase in the intensity of hurricanes.

We used data from a long-term study on St. John, U.S. Virgin Islands, to assess both the shortand long-term impacts of hurricanes on terrestrial bird populations and bird habitats. We were particularly interested in evaluating whether tropical storms had consistent and predictable effects on bird populations, and whether bird populations recovered following population declines after high-intensity hurricanes. The original focus of this study, when it began in 1987, was to determine which habitats were used by terrestrial bird species, especially winter-resident migrants (Askins et al. 1992). We completed standardized bird and vegetation surveys in the 2 dominant habitats (moist forest and dry woodland) on the island. After a major hurricane hit the island in 1989, we repeated the surveys to assess the effects of the storm on bird populations and the vegetation structure of their habitats (Askins and Ewert 1991). We continued to monitor birds at the same sites from 1990 to 1997 to determine the longerterm impact of the hurricane on bird populations. After 2 extremely powerful hurricanes hit the island in 2017, we returned to St. John to complete bird and vegetation surveys at the same sites to study the impact of the storms.

Our main goals in analyzing these long-term data are to determine (1) whether the 1989 and 2017 storms had similar effects on vegetation structure and bird populations, and (2) whether bird populations that declined after Hurricane Hugo in 1989 subsequently recovered between 1990 and 1997. This is one of the few studies to evaluate avian population responses to severe hurricanes occurring in different years at the same sites (Akresh et al. 2021).

\section{Study area}

We estimated the abundance of birds on 62 survey plots on St. John, U.S. Virgin Islands. All of the survey plots were in the interior of Virgin Islands National Park (18 $\left.20^{\prime} 34^{\prime \prime} \mathrm{N}, 64^{\circ} 44^{\prime} 54^{\prime \prime} \mathrm{W}\right)$ except for 7 plots straddling the park boundary, where half the plot was in the park and the other half included houses and gardens. Thus 55 of our survey plots were protected from development because they were inside the national park, and 7 
plots were only moderately affected by development.

We completed surveys on the same trails in 1987, 1990, 1992-1995, 1997, and 2019. Surveys were conducted in January of each year except 1987 when surveys occurred in mid-November and early December. Both the 1987 and later surveys occurred at the end of the 8 month rainy season (Woodbury and Weaver 1987) and after fall migration of landbirds had ended. Survey plots were located at $200 \mathrm{~m}$ intervals along each trail. All survey plots were located in the 2 dominant natural habitats on St. John (Woodbury and Weaver 1987): moist forest (40 plots) and dry woodland (22 plots). Moist forest, which is located on upper slopes, the floor of deep valleys, and coastal basins, is dominated by evergreen, broadleaved trees that are 10-30 m high (Woodbury and Weaver 1987). Dry woodland, which is found on steep, dry slopes, is dominated by small-leaved, thorny, evergreen trees that are 5-10 $\mathrm{m}$ high.

Three major hurricanes hit St. John during our study: Hurricane Hugo on 17-18 September 1989 with wind speeds of $209 \mathrm{kph}$, and Hurricanes Irma and Maria in 2017 with wind speeds of 298 and $274 \mathrm{kph}$, respectively (HurricaneCity 2020a, 2020b). Although both of the 2017 hurricanes were classified as Category 5, Hurricane Irma had a much bigger impact because the eye of the hurricane made landfall on St. John and the adjacent British Virgin Islands on 6 September (Cangialosi et al. 2018). In contrast, Hurricane Maria passed to the south of St. John, causing major damage on St. Croix. On St. John the wind was less intense than during Hurricane Irma, but heavy rainfall caused extensive flooding and mudslides on 19 September (Pasch et al. 2019).

\section{Bird surveys}

At each plot, we completed a 10 min survey, recording all individual birds that were seen or heard within a radius of $25 \mathrm{~m}$ and any additional individuals detected outside of this circle. A 10 min observation period was determined to be sufficient on the basis of a pilot study using a 20 min period (Askins et al. 1992). Birds of the same species were only counted as different individuals if they were heard or seen simultaneously. Records from within the circle are particularly important for determining the abundance of Bananaquits (see
Tables 1 and 2 for scientific names), warblers, hummingbirds, and other small birds that are not dependably detected in dense vegetation beyond $25 \mathrm{~m}$. A recording of "spishing" sounds (which are known to briefly attract small birds) was played during the second and sixth minutes of the observation period to facilitate visual identification of species.

Surveys were conducted between 0630 and $0930 \mathrm{~h}$ AST when birds are most active and vocal, and were not conducted when there was rain or heavy winds. Surveys were extended for up to an additional $5 \mathrm{~min}$ if a mixed-species flock with many individuals of different species occurred in the plot during the survey period to facilitate recording all members of the flock.

All surveys before 2019 were completed by the 2 principal investigators except for 5 survey points covered by another experienced investigator ( $R$. Norton) in 1987. By 2019 RAA had lost sensitivity to high-frequency sounds, reducing his ability to hear and localize the high-pitched call notes of warblers and Bananaquits, so another observer who had extensive experience in songbird surveys (D. Hitchcock) and DNE completed the bird surveys in 2019 .

\section{Vegetation surveys}

In 2019 measurements of vegetation structure were completed in each bird survey plot using the same methods we used in 1987 and 1990 (Askins et al. 1992). A $22 \mathrm{~m}$ diameter vegetation survey plot was located at the center of the bird survey plot. The vegetation plot was divided into 4 quadrants defined by north-south and east-west lines through the center. In 1987 and 2019 the height of the tallest tree in each quadrant was measured with a laser rangefinder and a Suunto clinometer, and the 4 heights were averaged to estimate mean maximum canopy height. In 1987 and 1990 we measured vegetation cover along 2 perpendicular $22 \mathrm{~m}$ transects that crossed at the center of the plot. In areas with extremely dense and/or thorny vegetation, these transects were run parallel to one another along each side of the trail. In 2019 we used parallel transects at all plots because the large amount of hurricane debris and dense understory made perpendicular transects impractical on the steep slopes that characterized 
Table 1. Results of log-linked Poisson models comparing abundance of particular bird species in the baseline year (1987) with their abundance in each of the subsequent years. Year was treated as a categorical variable in these models. Posthurricane years were 1990 and 2019 (bold font). For species that were largely restricted to either moist forest or dry woodland, only data from the most frequently used habitat were included in the analysis. For species that were frequent in both habitats, habitat type was included as a second independent variable along with year to determine whether they were more abundant in one habitat. Empty cells indicate $P>0.10$. Downward-pointing arrow $=$ lower abundance than in baseline year, upward-pointing arrow $=$ higher abundance than in baseline year, NA $=$ not applicable.

\begin{tabular}{|c|c|c|c|c|c|c|c|c|c|c|}
\hline Species & Scientific name & Habitat & 1990 & 1992 & 1993 & 1994 & 1995 & 1997 & 2019 & $\begin{array}{c}\text { Preferred } \\
\text { habitat }\end{array}$ \\
\hline American Redstart & Setophaga ruticilla & both & & & & & & & $\uparrow * *$ & moist $* * *$ \\
\hline American Redstart & Setophaga ruticilla & moist & & & & & & & $\uparrow *$ & NA \\
\hline Antillean Crested Hummingbird & Orthorhynchus cristatus & both & $\downarrow^{*}$ & & & & & & $\downarrow^{* *}$ & moist * \\
\hline Bananaquit & Coereba flaveola & both & $\downarrow * *$ & $\downarrow * *$ & & $\downarrow^{*}$ & $\downarrow * * *$ & & & \\
\hline Black-and-white Warbler & Mniotilta varia & both & $\downarrow^{*}$ & & $\downarrow^{*}$ & $\downarrow^{*}$ & $\downarrow *$ & $\downarrow *$ & $\downarrow^{*}$ & moist $* * *$ \\
\hline Black-and-white Warbler & Mniotilta varia & moist & $\downarrow *$ & & $\downarrow *$ & $\downarrow^{*}$ & $\downarrow *$ & $\downarrow *$ & & NA \\
\hline Caribbean Elaenia & Elaenia martinica & dry & $\downarrow^{\mathrm{a}}$ & $\downarrow^{\mathrm{a}}$ & & & & & & NA \\
\hline Gray Kingbird & Tyrannus dominicensis & dry & & $\downarrow^{\mathrm{a}}$ & $\downarrow^{\mathrm{a}}$ & & & $\downarrow^{\mathrm{a}}$ & & NA \\
\hline Green-throated Carib & Eulampis holosericeus & both & & & & & & & & dry $* *$ \\
\hline Lesser Antillean Bullfinch & Loxigilla noctis & dry & & & & & & $\uparrow *$ & $\downarrow^{\mathrm{a}}$ & NA \\
\hline Northern Parula & Setophaga americana & both & $\downarrow * *$ & $\downarrow *$ & $\downarrow * * *$ & $\downarrow * * *$ & $\downarrow * *$ & $\downarrow * * *$ & $\downarrow^{\mathrm{a}}$ & moist $* * *$ \\
\hline Northern Parula & Setophaga americana & moist & $\downarrow * *$ & $\downarrow^{* *}$ & $\downarrow * * *$ & $\downarrow * * *$ & $\downarrow * *$ & $\downarrow * * *$ & $\downarrow * *$ & NA \\
\hline Pearly-eyed Thrasher & Margarops fuscatus & both & & & $\downarrow^{*}$ & & & & $\downarrow^{*}$ & moist $* * *$ \\
\hline Pearly-eyed Thrasher & Margarops fuscatus & moist & & & & & $\uparrow * *$ & & & NA \\
\hline Pearly-eyed Thrasher & Margarops fuscatus & dry & $\downarrow *$ & $\downarrow * * *$ & $\downarrow^{*}$ & $\downarrow *$ & $\downarrow^{* *}$ & $\downarrow * * *$ & $\downarrow^{*}$ & NA \\
\hline Scaly-naped Pigeon & Patagioenas squamosa & moist & $\downarrow * * *$ & $\downarrow * * *$ & $\downarrow * * *$ & $\downarrow * * *$ & $\downarrow * * *$ & $\downarrow^{* *}$ & $\downarrow * * *$ & NA \\
\hline Yellow Warbler & Setophaga petechia & dry & & & & & & & & NA \\
\hline Zenaida Dove & Zenaida aurita & dry & & & & & & & & NA \\
\hline
\end{tabular}

our study sites. We did not complete vegetation surveys from 1992 to 1997.

Percent cover was estimated for 3 vertical layers: herb ( $<0.5 \mathrm{~m}$ high), shrub (0.5-4 m high), and tree ( $>4 \mathrm{~m}$ high). We stepped off the trail and sighted into each of these layers with an ocular tube (PVC tube that is $2.7 \mathrm{~cm}$ in diameter and 5.5 $\mathrm{cm}$ long) at 25 points at $2 \mathrm{~m}$ intervals along the 2

Table 2. Abundance (average number per survey plot) of species that were regularly detected during bird surveys but had sample sizes that were insufficient for statistical analysis of population changes. Post-hurricane years were 1990 and 2019 (bold font).

\begin{tabular}{|c|c|c|c|c|c|c|c|c|c|}
\hline Species $^{\mathrm{a}}$ & Scientific name & 1987 & 1990 & 1992 & 1993 & 1994 & 1995 & 1997 & 2019 \\
\hline Black-faced Grassquit & Melanospiza bicolor & 0.04 & 0.11 & 0.13 & 0.13 & 0.06 & 0.06 & 0.08 & 0.27 \\
\hline Black-throated Blue Warbler ${ }^{\mathbf{M}}$ & Setophaga caerulescens & 0.00 & 0.00 & 0.08 & 0.02 & 0.00 & 0.00 & 0.02 & 0.02 \\
\hline Bridled Quail-Dove $^{\mathbf{C}}$ & Geotrygon mystacea & 0.04 & 0.02 & 0.08 & 0.00 & 0.02 & 0.02 & 0.00 & 0.03 \\
\hline Common Ground Dove & Columbina passerina & 0.04 & 0.02 & 0.00 & 0.06 & 0.02 & 0.02 & 0.18 & 0.05 \\
\hline Hooded Warbler ${ }^{\mathbf{M}}$ & Setophaga citrina & 0.06 & 0.08 & 0.08 & 0.11 & 0.08 & 0.10 & 0.06 & 0.06 \\
\hline Magnolia Warbler $^{\mathbf{M}}$ & Setophaga magnolia & 0.04 & 0.05 & 0.03 & 0.02 & 0.00 & 0.00 & 0.02 & 0.00 \\
\hline Mangrove Cuckoo & Coccyzus minor & 0.04 & 0.02 & 0.00 & 0.10 & 0.02 & 0.03 & 0.02 & 0.00 \\
\hline Northern Waterthrush ${ }^{\mathbf{M}}$ & Parkesia noveboracensis & 0.00 & 0.08 & 0.05 & 0.00 & 0.02 & 0.02 & 0.03 & 0.03 \\
\hline Ovenbird $^{\mathbf{M}}$ & Seiurus aurocapilla & 0.13 & 0.16 & 0.05 & 0.00 & 0.00 & 0.05 & 0.05 & 0.03 \\
\hline Prairie Warbler ${ }^{\mathbf{M}}$ & Setophaga discolor & 0.04 & 0.03 & 0.03 & 0.06 & 0.00 & 0.10 & 0.06 & 0.05 \\
\hline Puerto Rican Flycatcher ${ }^{\mathrm{C}}$ & Myiarchus antillarum & 0.04 & 0.03 & 0.00 & 0.00 & 0.02 & 0.00 & 0.00 & 0.00 \\
\hline Smooth-billed Ani & Crotophaga ani & 0.06 & 0.05 & 0.00 & 0.02 & 0.00 & 0.02 & 0.00 & 0.00 \\
\hline Worm-eating Warbler ${ }^{\mathbf{M}}$ & Helmitheros vermivorum & 0.04 & 0.03 & 0.00 & 0.00 & 0.02 & 0.02 & 0.02 & 0.00 \\
\hline
\end{tabular}

\footnotetext{
${ }^{\text {a } \mathrm{M}}$ Winter-resident migrants from the North American temperate zone. ${ }^{\mathrm{C}}$ Species of greatest conservation concern in the U.S. Virgin Islands (Platenberg et al. 2005).
} 
transects (a central point where birds were counted during bird surveys plus 12 points along each of the 2 transects). At each point we categorized the percentage of the field of view in the ocular tube for each vegetation layer into the following categories: $0(0 \%), 1(1-25 \%), 2$ (26-50\%), 3 $(51-75 \%)$, or $4(76-100 \%)$. The sum of the 25 readings for a vegetation layer yielded an estimate of overall percent cover.

\section{Statistical analyses}

We compared the data for percent cover of vegetation for different years with one-way analysis of variance using the statistical package SPSS (IBM SPSS Statistics Version 25). Q-Q plots indicated that all of the percent-cover variables were approximately normally distributed, so the data did not require transformation. We used a Levene's test to determine whether there was a significant difference in variances among years. Depending on the results, we used either LSD tests (for equal variances) or Tamhane tests (for unequal variances) for pair-wise comparisons between years for percent cover of each vegetation layer. Because we only had data for 2 years for average canopy height, we used independent sample $t$-tests for this variable. A Q-Q plot showed that average canopy height had a normal distribution. We used a Levene's Test to determine whether to use results for $t$-tests that assume equal or unequal variances between years.

We compared the mean abundance of particular bird species (number per $25 \mathrm{~m}$ radius survey plot) for different years and for the 2 different habitats using a generalized linear model (GLM) with the statistical package R 3.4.3 (R Core Team 2017). Log-linked Poisson distribution models were used because bird count data were right skewed and included a number of zeros, which resulted in a non-normal distribution (O'Hara and Kotze 2010). For less common species that had a particularly large number of zeros, we also tried zero-inflated Poisson models (Zuur et al. 2010). However, for each of these species, we decided to use the simpler Poisson model because it fits the data better than a zero-inflated Poisson model based on Akaike's information criterion. Year was treated as a categorical variable (factor) in the GLM models as a fixed effect, so that we could compare results between particular years. It is appropriate to consider years as a categorical rather than as a continuous variable because 2 years (1990 and 2019) followed major hurricanes that greatly modified bird habitats, and because of the long gap between the 1997 and the 2019 surveys. We compared bird abundance in the baseline year (1987) vs. each of the other years. We considered 1987 to be an appropriate baseline year because it was the initial year for the analysis of long-term population changes and because the vegetation in 1987 had not been affected by a major hurricane for the previous 27 years since Hurricane Donna hit the island in 1960 (HurricaneCity 2020a). We did not use statistical models to analyze population changes if the sample size was too small (Chandler et al. 2009, Lloyd et al. 2019). Only bird species with an abundance of $\geq 0.2$ individuals/survey plot in either moist forest or dry woodland in at least 2 years were included in the analysis. For species that did not meet this cutoff value, we generally recorded $\leq 5$ individuals per year, so these species were not adequately sampled with our relatively small survey plots. We include information about the number of individuals detected each year for these infrequent species to reveal any patterns that might warrant further research, however.

Seven survey plots on Bordeaux Mountain Road were located on the boundary of the national park, so approximately half of the area of each of these plots was on private land. Houses and gardens were present at some of these parkboundary sites even in 1987, but the number of residences had increased by 2019 and the road had been paved. In 2019 all of these sites were still in predominantly forested landscapes, however. We compared the mean abundance of common bird species at park-boundary plots and park-interior plots for surveys completed between 1990 and 2019 to determine whether there were any major differences in species composition or population trends. We were not able to include 1987 plots in this comparison because the precise locations of plots along the road were uncertain, but the data from boundary plots were included along with the other Bordeaux Mountain plots in our statistical models comparing different years. Although the park-boundary plots were subject to development between 1990 and 2019, we did not find any clear differences in species composition or population trends between the park-boundary sites and moistforest sites in the interior of the national park 

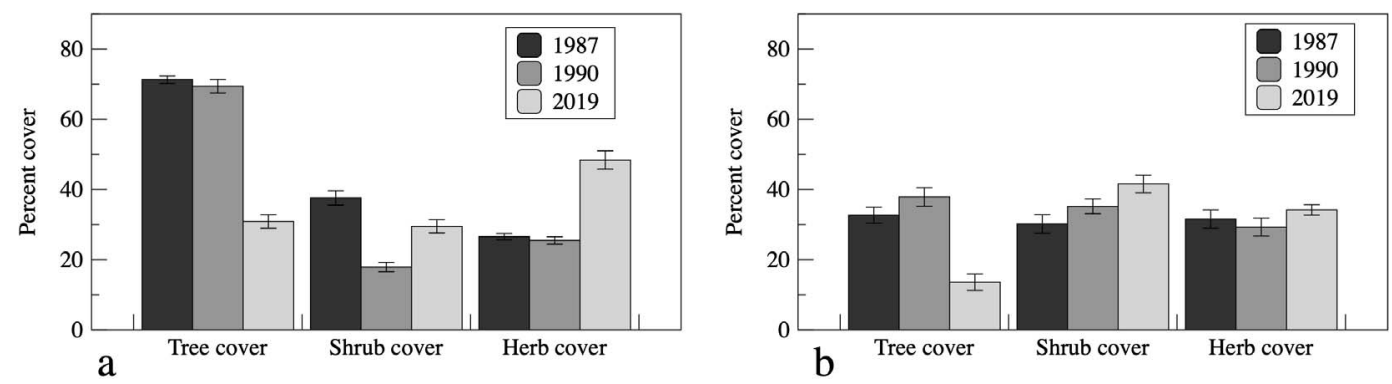

Figure 1. Percent cover of the tree layer ( $>4 \mathrm{~m}$ high), shrub layer $(0.5-4 \mathrm{~m}$ high), and herb layer $(<0.5 \mathrm{~m}$ high) in (a) moist forest and (b) dry woodland on St. John, U.S. Virgin Islands, in 1987 (2 years before Hurricane Hugo), 1990 (4 months after Hurricane Hugo), and 2019 (15 months after Hurricanes Irma and Maria).

except for Antillean Crested Hummingbird, which generally had higher abundance at park-boundary sites. The sample size for this species was insufficient to test this difference statistically, however. Given the similarity in population trends between park-interior and park-boundary plots, we pooled data from these 7 plots with the parkinterior plots for statistical analyses of population changes.

\section{Results}

\section{Effects of hurricanes on the vegetation}

In contrast to Hurricane Hugo in 1989, the 2 hurricanes in 2017 caused high mortality of trees on St. John, not just defoliation, because numerous trees were blown down or lost most of their branches (RAA and DNE, pers. obs.). The vertical structure of moist forest was therefore substantially different in 2019 than in the earlier 2 years when we completed vegetation surveys (Fig. 1a). In 2019 the percent cover of trees was significantly lower $(F=$ $173, \mathrm{df}=2,110, P<0.001)$ and the percent cover of herbs was significantly higher $(F=53$, df $=$ $2,110, P<0.001)$ than in either 1987 or 1990 . The percent cover of shrubs in 2019 was significantly lower than in $1987(F=31, \mathrm{df}=2,110, P<0.02)$ but significantly higher than in $1990(F=31, \mathrm{df}=$ $2,110, P<0.001)$. The only significant difference in moist forest structure following Hurricane Hugo was a decline in shrub density between 1987 and $1990(F=31$, df $=2,110, P<0.001)$. Despite major changes in tree cover, the average mean maximum canopy height did not differ significantly between 1987 and 2019 (12.4 and $12.9 \mathrm{~m}$, respectively; $t=0.86$, df $=71, P=0.39$ ). We did not measure mean canopy height in 1990 .
Changes in the tree cover for dry woodlands were similar to the changes in moist forest (Fig. 1b). In 2019 the percent cover of trees was significantly lower than in either 1987 or $1990(F$ $=26.6, \mathrm{df}=2,62, P<0.001)$. The percent cover of shrubs was significantly higher in 2019 than in $1987(F=5.3, \mathrm{df}=2,62, P=0.002)$ but did not differ between 1987 and $1990(F=5.3, \mathrm{df}=2,62$, $P=0.07)$. Herb cover values did not differ among the 3 years $(F=1.1, \mathrm{df}=2,62, P=0.34)$. Also, mean maximum canopy height did not differ significantly between 1987 and 2019 (6.7 and 6.5 $\mathrm{m}$, respectively; $F=0.50, \mathrm{df}=34, P=0.62$ ).

\section{Response of bird populations to hurricanes}

Thirteen species of birds had large enough sample sizes from bird surveys for statistical analyses of changes in abundance (Table 1). Five of these species did not show marked and consistent population declines or habitat shifts following hurricanes (Table 1, Fig. 2). In contrast, 5 other species (Antillean Crested Hummingbird, Green-throated Carib, Black-and-white Warbler, Caribbean Elaenia, and Scaly-naped Pigeon) showed population declines following major hurricanes in both 1989 and 2017 (Fig. 2). These declines were significant for Antillean Crested Hummingbird, Black-and-white Warbler, and Scaly-naped Pigeon (Table 1). Bananaquits declined significantly following the 1989 hurricane but not the 2017 hurricanes (Table 1, Fig. 2a).

Two other species showed complex patterns that may reflect habitat shifts between moist forests and dry woodlands following hurricanes. Pearly-eyed Thrashers declined significantly in dry woodlands but not in moist forest following the 1989 

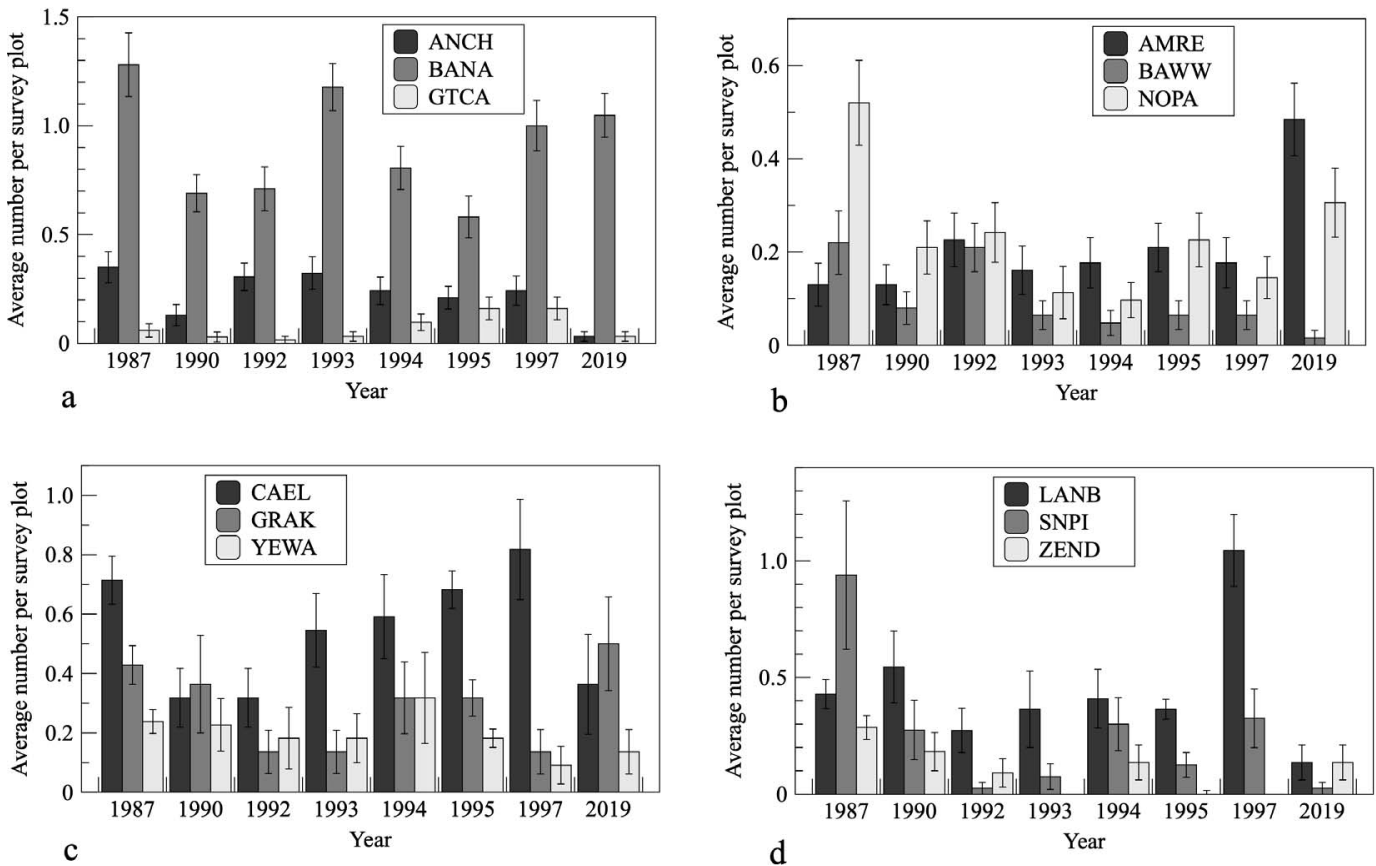

Figure 2. Changes in the average abundance for common species of birds on St. John, U.S. Virgin Islands. (a) Species that frequently feed on nectar in both moist forests and dry woodlands (ANCH - Antillean Crested Hummingbird, BANA Bananaquit, GTCA - Green-throated Carib), (b) winter-resident, insectivorous warblers in both moist forests and dry woodlands (AMRE - American Redstart, BAWW - Black-and-white Warbler, NOPA - Northern Parula), (c) resident insectivorous birds in dry woodland (CAEL - Caribbean Elaenia, GRAK - Gray Kingbird, and YEWA - Yellow Warbler), and (d) species of fruit- and seed-eating birds in dry woodlands (LANB and ZEND) or moist forest (SNPI) (LANB - Lesser Antillean Bullfinch, SNPI - Scaly-naped Pigeon, ZEND - Zenaida Dove). Major hurricanes occurred 4 months and 15 months before the surveys for 1990 and 2019, respectively.

hurricane (Table 1), but appeared to increase in dry woodlands and decline in moist forests compared to abundance in the late 1990s following the 2017 hurricanes (Fig. 3a). Northern Parulas were primarily found in moist forest and were generally

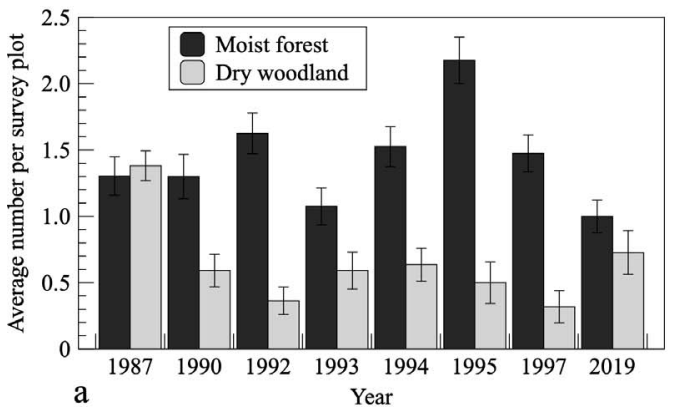

infrequent in dry woodlands (Table 1), but their abundance increased significantly in dry woodlands following the 1989 storm and also appeared to increase from 1990s levels following the 2017 storms (Fig. 3b).

Figure 3. Comparison of the average abundance in moist forests and dry woodlands for (a) Pearly-eyed Thrasher and (b) Northern Parula on St. John, U.S. Virgin Islands. Major hurricanes occurred 4 months and 15 months before the surveys for 1990 and 2019, respectively. 
Scaly-naped Pigeons and Zenaida Doves are legally hunted in the U.S. Virgin Islands (Nellis et al. 1984), so they tend to be warier of people than other species of landbirds. Consequently, their populations might have been underestimated on our relatively small survey plots if observers became more conspicuous after a hurricane opened up the forest canopy. We therefore assessed the abundance of Scaly-naped Pigeons and Zenaida Doves for unlimited survey data in which all detections from a survey point are recorded during the observation period regardless of distance from the observer. Both species have loud courtship calls that can be detected at great distances. This increased our sample size, but we did not analyze the results with statistical models because of the high probability that many of the observations were not independent (i.e., the same individuals were heard calling from 2 adjacent survey points). However, the number of observations of Scalynaped Pigeons in moist forest was exceptionally low in the aftermath of hurricanes for both $25 \mathrm{~m}$ radius surveys and unlimited-radius surveys. Changes in the abundance of Zenaida Doves showed similar patterns for $25 \mathrm{~m}$ and unlimitedradius surveys except in 1997, when this species was absent from $25 \mathrm{~m}$ surveys but frequent for unlimited-radius surveys.

Although the sample sizes for Black-faced Grassquit were too small for statistical analysis, this species was detected more frequently at moist forest plots in post-hurricane years (Table 2). We frequently observed grassquits in post-hurricane years in patches of moist forest where the tree canopy had been heavily damaged and the herbaceous layer was dense.

Sample sizes from standardized bird counts were also insufficient for assessing population changes for 2 species of special conservation concern in the Virgin Islands, the Bridled QuailDove and the Puerto Rican Flycatcher (Table 2). Both species were recorded in 2019, however, either during timed bird surveys or at other times during our field work on St. John. We found Bridled Quail-Doves at sites in Reef Bay Gut, Cinnamon Bay Gut, and Upper Carolina, and Puerto Rican Flycatchers at widely scattered locations in dry woodland on Brown Bay Trail, Bordeaux-Lameshur Trail, and Lameshur Bay Trail (see eBird 2020 for locations).

\section{Long-term population change vs. response to hurricanes}

Because of the long gap between the 1997 and 2019 surveys, population declines in 2019 could be due to either long-term population trends or to the negative effects of the 2017 hurricanes. We cannot conclusively separate these 2 plausible hypotheses, but we can assess whether a population changed consistently between 1987 and 2019, indicating a long-term population trend. Three of the 5 species that declined following both the 1989 and 2017 hurricanes (Antillean Crested Hummingbird, Green-throated Carib, and Caribbean Elaenia) showed fluctuations in abundance without consistently increasing or decreasing between 1987 and 2019 (Fig. 2). The 2 remaining species showed patterns that were consistent with longterm population declines. Black-and-white Warblers had significantly lower abundance after 1987 except for a 1 year increase in 1992, indicating a long-term population decline (Table 1, Fig. 2b). Scaly-naped Pigeon abundance was also significantly lower in the years after 1987 (Table 1, Fig. 2d). However, this long-term decline is not apparent for data from unlimited-radius surveys, which indicate exceptionally high numbers for Scaly-naped Pigeons between 1993 and 1997.

\section{Evidence of recovery from Hurricane Hugo}

Of the 5 species that showed population declines after the 1989 and 2017 hurricanes, 3 species (Antillean Crested Hummingbird, Green-throated Carib, and Caribbean Elaenia) appeared to recover between 1992 and 1997 (Fig. 2). As described above, the abundance of both Black-and-white Warbler and Scaly-naped Pigeon showed long-term declines, never returning to the levels for 1987 for surveys of $25 \mathrm{~m}$ radius plots. Data from unlimitedradius plots indicate that Scaly-naped Pigeons may have recovered after the 1989 hurricane, however. In addition, Bananaquits, which showed a significant drop in abundance after the 1989 hurricane but not the 2017 storms, had recovered by 1993 (Table 1, Fig. 2a).

\section{Discussion}

The impact of hurricanes on vegetation structure was much greater in 2017 than 1989. After Hurricane Hugo in 1989, the only significant 
impact on vegetation structure was lower shrub density in moist forests that may have resulted from a decline in shade-tolerant plants following canopy defoliation after a long period with no major storms (Askins and Ewert 1991). In contrast, heavy tree and branch mortality in 2019 resulted in a substantial reduction in the tree cover in both moist forest and dry woodland, and an increase in herbaceous density in moist forest. The shrub density also increased since 1990 in both habitats. These changes occurred despite maturation of the forest during the past 32 years.

Despite the substantial difference in the strength of the 1989 and 2017 storms and their major effects on vegetation structure, the pattern of population changes for some species of birds was fairly similar. Five of the 13 species with sufficient sample sizes for statistical analysis showed population declines following both the 1989 and 2017 storms. Bananaquits, Pearly-eyed Thrashers, and Northern Parulas declined following the 1989 storm but not after the 2017 storms when data from all survey plots were included in the analysis. However, the latter 2 species showed different patterns of population change in moist forests and dry woodlands, suggesting that changes in abundance were influenced by habitat shifts following storms. Northern Parulas increased in dry woodlands in both 1990 and 2019, while Pearly-eyed Thrashers declined in dry woodlands in 1990 but appeared to increase in this habitat in 2019.

The 1990 surveys occurred 4 months after Hurricane Hugo and the 2019 surveys occurred 15 months after Hurricanes Irma and Maria. Consequently, some bird populations may have already recovered to some extent by 2019. This is particularly likely for Bananaquits, which may be capable of rapid population growth. Color-banded Bananaquits have up to 3 successful nesting attempts per year, which may shorten recovery periods (J.M. Wunderle Jr., International Institute of Tropical Forestry, U.S. Forest Service, pers. comm.). After Hurricane Hugo, Bananaquits not only had a lower population on St. John (Askins and Ewert 1991), but also on the nearby island of St. Croix (Wauer and Wunderle 1992), but these surveys occurred 4 and 7 months after the storm, respectively. By January 2019, 15 months after the 2017 storms, Bananaquits may have successfully produced numerous young. Also, survival rates for Bananaquits may have been boosted on St. John because of a coordinated effort by a large number of people on the island to provision Bananaquits with sugar during the immediate aftermath of the storms (P. Benton, Virgin Islands Audubon Society, and L. Brannick, U.S. National Park Service, pers. comm.).

The negative impact of hurricanes on species that depend on nectar as a major food source has been documented in numerous studies on other islands in the Caribbean Basin (Waide 1991a, Wunderle et al. 1992, Wiley and Wunderle 1993, Lloyd et al. 2019). Bananaquits, Antillean Crested Hummingbirds, and Green-throated Caribs showed marked declines after Hurricane Hugo hit St. Croix in 1989 (Wauer and Wunderle 1992) and following Hurricanes Irma and Maria in northeastern Puerto Rico in 2018 (J.M. Wunderle Jr., pers. comm.). These 3 nectarivorous species also declined on St. John following storms. Antillean Crested Hummingbirds and Greenthroated Caribs showed substantial declines on St. John in the aftermath of hurricanes in both 1990 and 2019, and Bananaquits showed a major decline in 1990. Although nectarivores may have suffered mortality during storms, the main cause of their decline was probably the absence of flowers in the weeks or months after a storm (Waide 1991a). Flowers are blown away by hurricanes, and plants produce few new flowers while leaves are being replaced after the massive defoliation caused by hurricanes. Nectarivore populations may recover as plants begin to produce flowers again, but declines in the abundance of particular species of plants as a result of a hurricane may lead to longer-term changes in relative abundance and niche overlap of different species of hummingbirds (Infante et al. 2020).

Fruit is also destroyed by hurricanes and is not replaced during the period when plants are replacing leaves, so fruit-eating birds also tend to decline following hurricanes (Waide 1991a, Wauer and Wunderle 1992, Wunderle et al. 1992). Scalynaped Pigeons declined at our survey plots after major hurricanes in both 1990 and 2019. This species is highly mobile, however, moving between habitats on the same island and even between islands (Wiley and Wunderle 1993, Gibbs et al. 2001), so an apparent population decline may actually reflect a habitat shift or local movements to fruit-rich sites rather than an overall decrease in abundance (Wunderle 2017). Also, nesting and 
courtship calling can occur at any time of year in this species depending on food availability (Gibbs et al. 2001, Rivera-Milán 2001), so its detectability may vary during the same season in different years depending on whether these pigeons are breeding. In addition, we found that counts of Scaly-naped Pigeons were inconsistent for $25 \mathrm{~m}$ survey plots and unlimited-radius survey plots, indicating that they were not reliably detected on small survey plots. Interpretations of changes in abundance in response to hurricanes are inconclusive given their mobility and potential differences in detectability from year-to-year. Assessment of population changes in this species would be better accomplished with a research design similar to that used by Nellis et al. (1984). They monitored Scalynaped Pigeon populations each month for several years using roadside surveys that traversed numerous habitats.

Another fruit-eating species, the Bridled QuailDove, was too infrequent on our survey plots to permit statistical analysis. We found this species at several sites in 2019, indicating that some individuals survived the effects of the storms (eBird 2020). Bridled Quail-Doves were thought to be extirpated on St. Croix as a result of Hurricane Hugo (Wauer and Wunderle 1992), but they were subsequently found at many locations on that island, with numerous observations in 2019 (eBird 2020). However, an intensively monitored population of Bridled Quail-Doves in St. Eustatius declined by $76 \%$ during the 8 months after Hurricanes Irma and Maria (Madden et al. 2018), further suggesting that this species suffers at least short-term population declines as a result of hurricanes.

Populations of insectivorous birds are typically not greatly affected by major hurricanes because insect populations rapidly recover after a storm (Waide 1991a). The abundance of 3 primarily insectivorous species, Gray Kingbird, American Redstart, and Yellow Warbler, did not consistently decline in response to the 1989 and 2017 hurricanes. Among the insectivorous species with adequate sample sizes for statistical analysis, only Black-and-white Warbler and Caribbean Elaenia showed declines following major hurricanes in both 1990 and 2019. Caribbean Elaenia feeds on both insects and fruit. In some regions they primarily feed on fruit (Crowell 1968), so scarcity of fruit may account for their decline after storms.
Black-and-white Warblers also declined following hurricanes in shade coffee plantations in Jamaica (Wunderle et al. 1992) and in dry forest in Puerto Rico (Dugger et al. 2004). Black-and-white Warblers feed on bark and foliage insects (Kricher 2020), so damage to branches and twigs in the overstory may reduce their food supply (Wiley and Wunderle 1993). However, on St. John Black-andwhite Warblers showed a long-term decline between 1987 and 2019, so their lower numbers in 2019 may be due to factors other than the 2017 hurricanes. Most winter-resident Black-and-white Warblers from the Caribbean region that includes St. John probably breed from North and South Carolina west to Missouri and Arkansas (C.E. Studds, University of Maryland, unpubl. data) where Black-and-white Warblers declined at a rate of $0.2-1.7 \%$ per year between 1966 and 2015 (Sauer et al. 2017). Hence, the decrease in Blackand-white Warblers on St. John since 1987 corresponded with a decrease in their likely breeding populations. One insectivore, Northern Parula, and one omnivore, Pearly-eyed Thrasher, showed changes in relative abundance in moist forests and dry woodland that are consistent with habitat shifts in response to storm damage. Wauer and Wunderle (1992) also found that Pearly-eyed Thrashers increased in dry woodland and declined in moist forest on St. Croix following Hurricane Hugo.

Black-faced Grassquits are seed-eaters and are generally found in open and disturbed habitats outside of the Virgin Islands National Park. Although the sample sizes were too small for statistical analysis, their numbers increased in plots where moist forest had been damaged recently by hurricanes. Black-faced Grassquits were also detected in woodland areas more frequently after hurricanes in Puerto Rico (Waide 1991b). They may be attracted to grass seeds in forest openings created by storms (J.M. Wunderle Jr., pers. comm.).

An important qualification in interpreting data on bird populations after hurricanes is that major changes in vegetation such as the opening of the forest canopy can change the detectability of birds during standardized surveys (Wiley and Wunderle 1993). Birds may be easier to see and hear in a more open post-hurricane habitat, and species that are normally high in the trees may be forced to forage in lower vegetation (Wunderle et al. 1992). 
Lloyd et al. (2019) found that most bird species showed relatively little change in detectability in Puerto Rico following Hurricanes Irma and Maria, but Bananaquit and Scaly-naped Pigeon showed substantially lower detectability. Our surveys should be relatively resistant to this bias because we only included birds detected within $25 \mathrm{~m}$ of the observer in our analysis, and most birds were detected by vocalizations such as the songs and calls of permanent-resident species and the "chip" notes of warblers.

Our surveys between 1990 and 1997 permitted us to assess whether species that declined following Hurricane Hugo subsequently increased to pre-hurricane abundance. Antillean Crested Hummingbird, Green-throated Carib, Bananaquit, and Caribbean Elaenia populations recovered during the 8 years after the storm. Scaly-naped Pigeons and Black-and-white Warblers never reached their 1987 population abundance in later years, but Scaly-naped Pigeon populations were not adequately sampled using small survey plots and Black-and-white Warblers may have shown a long-term population decline due to factors unrelated to the occurrence of hurricanes. In 2019, however, there was little indication of recovery from the 2017 hurricanes except perhaps for Bananaquits. Resilience of these populations to the 2017 storms would best be assessed after more time has passed since the storms.

Our results indicate that most bird populations on St. John were resilient following a major hurricane in 1989 and later survived 2 of the strongest hurricanes ever recorded in the Virgin Islands. However, the populations of especially vulnerable species such as Bridled Quail-Dove, Scaly-naped Pigeon, Antillean Crested Hummingbird, Green-throated Carib, and Puerto Rican Flycatcher should be monitored with more focused studies. Also, protection of large areas of continuous natural habitat that extend from shoreline to the central ridgetop on the island within Virgin Islands National Park is critically important for sustaining a diversity of terrestrial birds (Steadman et al. 2009). Extensive areas of natural habitat not only support large populations, but also permit habitat shifts during periods of resource scarcity such as the aftermath of major hurricanes. The areas outside of the national park have been heavily developed since 1987 , so it is particularly important to maintain the continuity of natural habitats within the park.

\section{Acknowledgments}

Our research in 2019 would not have been possible without financial support from the Friends of Virgin Islands National Park. We greatly appreciate the assistance of K. Askins, D. Hitchcock, and R. McMahon in collecting and compiling field data during January 2019. C. Rogers has supported and helped guide our research since our first field season in 1987 and is the main reason a 3 month study developed into a long-term research project. J. Wunderle Jr. also provided important advice and support during the early years of this project and he made many helpful comments on a draft of this paper. We also thank L. Brannick for her assistance in Virgin Islands National Park. M. Akresh at Antioch University provided invaluable advice and guidance on the statistical models. P. Benton, who is the compiler of the Christmas Bird Count results for St. John, provided information and insights about the impact of the 2017 hurricanes on birds. We thank the National Geographic Society, International Institute of Tropical Forestry of the U.S. Forest Service, World Nature Association, U.S. National Park Service, National Biological Service, The Nature Conservancy, Connecticut College, the American Bird Conservancy, Caneel Bay Resorts, and Maho Bay Camps for supporting our research between 1987 and 2019. We are also grateful to R. Norton, J. Markow, J. Trimble, H. Brawley, and B. Shea for help with field work during the period between 1987 and 1997. Reviews by E. Andresen and an anonymous reviewer greatly improved the organization and clarity of this paper.

\section{Literature cited}

Akresh ME, Askins RA, King DI, Hayes FE, Barry PE, Hayes WK. 2021. Resilience in the aftermath of hurricanes: Fluctuations in a critically endangered population of West Indian Woodpeckers (Melanerpes superciliaris nyeanus) over two decades. Bird Conservation International. 31:185-205.

Askins RA, Ewert DN. 1991. Impact of Hurricane Hugo on bird populations on St. John, U.S. Virgin Islands. Biotropica. 23:481-487.

Askins RA, Ewert DN, Norton R. 1992. Abundance of wintering migrants in fragmented and continuous forests in the U.S. Virgin Islands. In: Hagan JW, Johnston DW, editors. Ecology and conservation of Neotropical migrant landbirds. Washington (DC): Smithsonian Press; p. 197-206.

Bhatia KT, Vecchi GA, Knutson TR, Murakami H, Kossin J, et al. 2019. Recent increases in tropical cyclone intensification rates. Nature Communications. 10:635.

Cangialosi JP, Latto AS, Berg R. 2018. Hurricane Irma. National Hurricane Center tropical cyclone report. Miami (FL): National Weather Service, National Oceanic and Atmospheric Administration.

Chandler RB, King DI, Chandler CC. 2009. Effects of management regime on the abundance and nest 
survival of shrubland birds in wildlife openings in northern New England, USA. Forest Ecology and Management. 258:1669-1676.

Crowell KL. 1968. Competition between two West Indian flycatchers, Elaenia. Auk. 85:265-286.

Dugger KM, Faaborg J, Arendt WJ, Hobson KA. 2004. Understanding survival and abundance of overwintering warblers: Does rainfall matter? Condor. 106:744760.

eBird. 2020. eBird: An online database of bird distribution and abundance [cited 18 Dec 2020]. Ithaca (NY): Cornell Lab of Ornithology. http://www.ebird.org

Ercolani C, Muller J, Collins J, Savarese M, Squiccimara L. 2015. Intense southwest Florida hurricane landfalls over the past 1000 years. Quaternary Science Review. 126:17-25.

Field CR, Ruskin KJ, Cohen JB, Hodgman TP, Kovach AI, et al. 2019. Framework for quantifying population responses to disturbance reveals that coastal birds are highly resilient to hurricanes. Ecology Letters. 22:2039-2048.

Foster JT, Tweed EJ, Camp RJ, Woodworth BL, Adler CD, Telfer T. 2004. Long-term population changes of native and introduced birds in the Alaka'i Swamp, Kaua'i. Conservation Biology. 18:716-725.

Francis JK, Gillespie AJR. 1993. Relating gust speed to tree damage in Hurricane Hugo, 1989. Journal of Arboriculture. 19:368-373.

Gibbs D, Barnes E, Cox J. 2001. Pigeons and doves: A guide to pigeons and doves of the world. New Haven (CT): Yale University Press.

Haney JC, Wunderle JM Jr, Arendt WJ. 1991. Some initial effects of Hurricane Hugo on endangered and endemic species of West Indian birds. American Birds. 45:234 236.

HurricaneCity. 2020a. Saint Thomas and Saint John, Virgin Island's history with tropical systems [cited 29 Dec 2020]. Delray Beach (FL): HurricaneCity. http://www. hurricanecity.com/city/saintthomas.htm

HurricaneCity. 2020b. Saint Croix, Virgin Island's history with tropical systems [cited 29 Dec 2020]. Delray Beach (FL): HurricaneCity. http://www.hurricanecity. com/city/saintcroix.htm

Infante SD, Lara C, del Coro Arizmendi M. 2020. Temporal dynamics of the hummingbird-plant interaction network of a dry forest in Chamela, Mexico: A 30-year follow-up after two hurricanes. PeerJ. 8:e8338.

Johnson AB, Winker K. 2010. Short-term hurricane impacts on a Neotropical community of marked birds and implications for early-stage community resilience. PLOS One. 5(11):e15109.

Johnson TH, Stattersfield AJ. 1990. A global review of island endemic birds. Ibis. 132:167-180.

Knutson T, Camargo SJ, Chan JCL, Emanuel K, Ho C-H, et al. 2019. Tropical cyclones and climate assessment. Part 1: Detection and attribution. Bulletin of the American Meteorological Society. 100:1987-2007.

Kricher JC. 2020. Black-and-white Warbler (Mniotilta varia), version 1.0. In: Poole A, editor. Birds of the world. Ithaca (NY): Cornell Lab of Ornithology. https://doi.org/10.2173/bow.bawwar.01

Lloyd JD, Rimmer CC, Salguero-Faría JA. 2019. Short-term effects of Hurricanes Maria and Irma on forest birds of Puerto Rico. PLOS One. 14(6): 0214432.

Madden H, Rivera-Milán FF, Verdel K. 2018. St. Eustatius: The Bridled Quail-Dove struggles for survival following hurricanes. Birds Caribbean. https://www. birdscaribbean.org/2018/11/st-eustatius-the-bridledquail-dove-struggles-for-survival-following-hurricanes

Moreno AC, Carrascal LM, Delgado A, Suárez V, Seoane J. 2018. Striking resilience of an island endemic bird to a severe perturbation: The case of the Gran Canaria Blue Chaffinch. Animal Biodiversity and Conservation. 41:131-140.

Nellis DW, Dewey RA, Hewitt MA, Imsand S, Philibosian R, Yntema JA. 1984. Population status of Zenaida Doves and other columbids in the Virgin Islands. Journal of Wildlife Management. 48:889-894.

O'Hara RB, Kotze DJ. 2010. Do not log-transform count data. Methods in Ecology and Evolution. 1:118-122.

Pasch RJ, Penny AB, Berg R. 2019. Hurricane Maria. National Hurricane Center tropical cyclone report. Miami (FL): National Weather Service, National Oceanic and Atmospheric Administration.

Platenberg RJ, Hayes FE, McNair DB, Pierce JJ. 2005. A comprehensive wildlife conservation plan for the U.S. Virgin Islands. St. Thomas (U.S. Virgin Islands): Division of Fish and Wildlife.

R Core Team. 2017. R: A language and environment for statistical computing. Vienna (Austria): R Foundation for Statistical Computing.

Rivera-Milán FF. 2001. Transect surveys of columbid nests on Puerto Rico, Vieques, and Culebra Islands. Condor. 103:332-342.

Sauer JR, Niven DK, Hines JE, Ziolkowski DJ Jr, Pardieck KL, et al. 2017. North American Breeding Bird Survey, results and analysis 1966-2015 [cited 24 May 2019]. Laurel (MD): USGS, Patuxent Wildlife Research Center Version 2.07.2017. https://www.mbr-pwrc. usgs.gov/bbs/bbs.html

Schowalter TD, Willig MR, Presley SJ. 2017. Post-hurricane successional dynamics in abundance and diversity of canopy arthropods in a tropical rainforest. Environmental Entomology. 46:11-20.

Simberloff D. 2000. Extinction-proneness of island species - Causes and management implications. Raffles Bulletin of Zoology. 48:1-9.

Spatz DR, Zilliacus KM, Holmes ND, Butchart SHM, Genovesi P, et al. 2017. Globally threatened vertebrates on islands with invasive species. Science Advances. 3:e1603080.

Steadman DW, Montambault JR, Robinson SK, Oswalt SN, Brandeis TJ, et al. 2009. Relative abundance, habitat use, and long-term population changes of wintering and resident landbirds on St. John, U.S. Virgin Islands. Wilson Journal of Ornithology. 121:41-53.

Tershy BR, Shen K-W, Newton KM, Holmes ND, Croll DA. 2015. The importance of islands for the protection of 
biological and linguistic diversity. BioScience. 65:592597.

Torres JA. 1992. Lepidoptera outbreaks in response to successional changes after the passage of Hurricane Hugo in Puerto Rico. Journal of Tropical Ecology. 8:285-298.

Varty N. 1991. The status and conservation of Jamaica's threatened and endemic forest avifauna and their habitats following Hurricane Gilbert. Bird Conservation International. 1:135-151.

Waide RB. 1991a. Summary of the response of animal populations to hurricanes in the Caribbean. Biotropica. 23:508-512.

Waide RB. 1991b. The effect of Hurricane Hugo on bird populations in the Luquillo Experimental Forest, Puerto Rico. Biotropica. 23:475-480.

Walker LR, Lodge DJ, Brokaw NVL, Waide RB. 1991. An introduction to hurricanes in the Caribbean. Biotropica. 23:313-316.

Wauer RH, Wunderle JM Jr. 1992. The effect of Hurricane Hugo on bird populations on St. Croix, U.S. Virgin Islands. Wilson Bulletin. 104:656-673.
Wiley J, Wunderle JM Jr. 1993. The effects of hurricanes on birds, with special reference to Caribbean Islands. Bird Conservation International. 3:319-349.

Woodbury RO, Weaver PL. 1987. The vegetation of St. John and Hassel Island, U.S. Virgin Islands. Atlanta (GA): Southeast Regional Office, U.S. National Park Service. Research/Resource Management Report SER-83.

Wunderle JM Jr. 1999. Pre- and post-hurricane fruit availability: Implications for Puerto Rican Parrots in the Luquillo Mountains. Caribbean Journal of Science. 35:249-264.

Wunderle JM Jr. 2017. Effects of Hurricanes Irma and Maria on birds in the Fajardo Christmas Bird Count in northeastern Puerto Rico: A preliminary assessment. Acta Cientifica. 31:18-33.

Wunderle JM Jr, Lodge DJ, Waide RB. 1992. Short-term effects of Hurricane Gilbert on terrestrial bird populations on Jamaica. Auk. 109:148-166.

Zuur AF, Ieno EN, Elphick CS. 2010. A protocol for data exploration to avoid common statistical problems. Methods in Ecology and Evolution. 1:3-14. 